\title{
The effects of osmotic upshock on the intracellular solute pools of Bacillus subtilis
}

\author{
Adrian M. Whatmore, ${ }^{1 *} \dagger$ John A. CHUdeK ${ }^{2}$ and Robert H. ReED ${ }^{1} \ddagger$ \\ Departments of ${ }^{1}$ Biological Sciences and ${ }^{2}$ Chemistry, University of Dundee, Dundee DD1 4HN, UK
}

(Received 24 April 1990; revised 29 July 1990; accepted 3 September 1990)

\begin{abstract}
The effects of hypersaline treatment (osmotic upshock) on solute accumulation have been studied in the Grampositive bacterium Bacillus subtilis. Natural abundance ${ }^{13} \mathrm{C}$ NMR spectroscopy studies revealed only proline as a major organic osmoticum in cells grown in defined medium (no exogenous organic solutes) and this finding was confirmed by amino acid analysis. Intracellular concentrations of both $\mathrm{K}^{+}$and proline rose markedly after osmotic upshock. $\mathrm{K}^{+}$influx from the medium was rapid $(<1 \mathrm{~h})$ but proline synthesis was a slower process $(5-9 \mathrm{~h})$. Proline synthesis appeared to be dependent on the prior accumulation of $\mathrm{K}^{+}$and it is possible that $\mathrm{K}^{+}$serves in some manner as the signal for increased proline synthesis. In cells upshocked in medium enriched in glycine betaine the endogenous synthesis of proline was repressed and glycine betaine served as the sole organic osmoticum. $\mathrm{K}^{+}$was also accumulated under these conditions.
\end{abstract}

\section{Introduction}

The responses of bacterial cells to a hyperosmotic environment have received much attention in recent years (see Csonka, 1989). All organisms must be able to adapt to fluctuations in environmental osmolality in order to maintain a positive turgor pressure. When a cell is subjected to a sudden osmotic upshock (increase in external osmolality) the internal osmotic pressure falls due to the rapid outflow of water. To restore turgor pressure and allow growth to continue, a cell must restore its internal osmotic pressure to a level exceeding that of the environment. This is achieved by the accumulation of various solutes by uptake and/or metabolic interconversion, often to very high concentrations leading to an influx of water into the cells and the restoration of turgor (Brown, 1976). The term 'compatible solute' was introduced by Brown \& Simpson (1972) to describe accumulated solutes which are non-inhibitory to enzyme function at high concentration, i.e. compatible with cellular metabolism.

A diverse range of organic solutes are accumulated as compatible solutes in various micro-organisms; these solutes include carbohydrates, amino acids, imino acids,

† Present address: Department of Microbiology, New Medical School, University of Newcastle, Newcastle upon Tyne NE2 4HH, UK.

$\ddagger$ Present address: Department of Chemical and Life Sciences, Newcastle Polytechnic, Newcastle upon Tyne NE1 8ST, UK. quaternary ammonium compounds and tertiary sulphonium compounds. Osmotic responses of bacteria have been best studied in Gram-negative enteric bacteria, notably Escherichia coli and Salmonella typhimurium (Booth et al., 1988; Higgins et al., 1987). A complex, integrated response occurs in these organisms involving accumulation of $\mathrm{K}^{+}$, glutamic acid, glycine betaine and trehalose depending on the degree of upshock and the chemical nature of the environment (Imhoff, 1986; Dinnibier et al., 1988). There is little similar data regarding the responses of Gram-positive bacteria to osmotic upshock. The neutral amino acids proline, glutamine and alanine are synthesized in Streptomyces (Killham \& Firestone, 1984) while glutamine is synthesized and proline taken up in Staphylococcus aureus at the expense of glutamic and aspartic acids (Anderson \& Witter, 1982). Additionally, the use of complex media has often made previous studies difficult to interpret: it is often unclear whether solutes are being synthesized de novo or transported into the cell from the medium.

Bacillus subtilis has been shown to accumulate proline in response to osmotic upshock (Measures, 1975; Gould $\&$ Measures, 1977), although the nature of the medium used in these studies is unclear. Specific chemical assays designed to quantify a specific osmolyte or class of osmolyte were used, with the possibility of overlooking other solutes. A more powerful technique is natural abundance ${ }^{13} \mathrm{C}$ nuclear magnetic resonance spectroscopy (NMR) - this technique provides a means of 
identifying all of the major organic solutes in biological material from their characteristic NMR profiles. The only potential osmoregulatory solutes not detected are inorganic ions. Natural abundance ${ }^{13} \mathrm{C}$ NMR has been used to identify the organic osmotica in filamentous fungi (Gadd et al., 1984), cyanobacteria (Reed et al., 1985b), algae (Reed et al., 1985a) and certain Gramnegative (Larsen et al., 1987) and Gram-positive (Hutkins et al., 1987) bacteria. Such use of NMR enables preliminary identification of all major organic solutes which then permits the selection of specific chemical assays or other rapid quantitative techniques for further work, examining the characteristics of accumulation.

This paper provides the first unequivocal data for the intracellular solute profile of B. subtilis and the effect of osmotic upshock on this profile, based on NMR analysis, and the first evidence of $\mathrm{K}^{+}$-dependent osmoregulatory organic solute synthesis in a Gram-positive bacterium.

\section{Methods}

Organism, media and growth conditions. Bacillus subtilis NCIB 1650 , obtained from the National Collection of Industrial Bacteria, Aberdeen, UK, was routinely maintained on nutrient agar at $25^{\circ} \mathrm{C}$. The defined liquid medium used in this study is described in the preceding paper (Whatmore \& Reed, 1990); the $\mathrm{K}^{+}$-free medium used was as above with the omission of the $\mathrm{KCl}$. All experimental flasks were inoculated with exponentially growing cultures $(10 \mathrm{~h})$. All experiments were done at $25^{\circ} \mathrm{C}$ unless stated otherwise. Unless stated otherwise all measurements of internal solute concentrations represent the mean \pm $95 \%$ confidence limits $(1.96 \times \mathrm{SE})$ of three or four replicates.

Determination of cell number and volume. Cells were sized and counted using a Coulter counter (ZBI) and C1000 Channelyzer linked to an Acorn microcomputer as described by Whatmore \& Reed (1990).

Nuclear magnetic resonance (NMR) spectroscopy. Samples for ${ }^{13} \mathrm{C}$ NMR were cultured in 121 flasks containing 101 of medium with constant sparging using sterile air. Samples were harvested in the midexponential phase by continuous centrifugation and rinsed in isotonic salt solution to remove any traces of adhering glucose from the growth medium. Harvested cells were extracted twice overnight in $80 \%(\mathrm{v} / \mathrm{v})$ ethanol and centrifuged to remove cellular debris; the residue was then dried in a rotary evaporator. Samples were freeze-dried overnight, dissolved in $1 \mathrm{ml} \mathrm{D}_{2} \mathrm{O}$ and filtered (Millipore cellulose nitrate, pore size $0.45 \mu \mathrm{m})$. Natural abundance ${ }^{13} \mathrm{C}$ NMR spectra were obtained using a Bruker WP360 FT spectrometer. Values are expressed as $\delta=$ observed shift/spectrometer frequency (p.p.m.).

Intracellular glycine betaine was identified and quantified by ${ }^{1} \mathbf{H}$ NMR (Chudek et al., 1987). Samples varying from 320 to $100 \mathrm{ml}$ were harvested and rinsed in isotonic salt solution and prepared as for ${ }^{13} \mathrm{C}$ NMR with sodium acetate added as an internal standard. Estimates of the sample size required to generate a suitable signal were based on concentrations of proline previously seen after upshock. Since $1 \mathrm{mg}$ glycine betaine is equivalent to $2.1 \mathrm{mg}$ sodium acetate in terms of ${ }^{1} \mathbf{H}$ NMR peak area, the amount of glycine betaine present in each sample could be quantified from the peak area, relative to that of the internal standard. Samples were analysed with a Bruker HX90 continuous wave spectrometer operating at $90 \mathrm{MHz}$. Line positions were measured relative to 3-(trimethylsilyl)propanesulphonic acid (sodium salt). Measurements were made using the trimethyl resonance of glycine betaine at $\delta_{\mathrm{H}}=3.26$ p.p.m. and for acetate at $\delta_{\mathrm{H}}=1.29$ p.p.m. The methylene signal of glycine betaine was not used due to weak signal intensity.

Extraction and measurement of amino acid pools. Samples for amino acid analysis were harvested by centrifugation and extracted overnight in $80 \%(\mathrm{v} / \mathrm{v})$ ethanol. After removal of debris by centrifugation, samples were evaporated to dryness on a photographic warmplate and then redissolved in $200 \mathrm{mM}$-lithium hydroxide/sodium citrate buffer, pH 2.2. After filtration (Millipore cellulose nitrate, pore size $0.45 \mu \mathrm{m}$ ), amino acids were analysed on a LKB-4400 Amino Acid Analyzer using a lithium citrate buffer system. $n$-Leucine was used as the internal standard.

Determination of intracellular free proline. A modification of the method of Bates et al. (1973) was used for rapid determination of free proline. The method is a simple colorimetric determination which proved adequate to quantify the relatively large amounts of proline found in this organism. The colour yield of interfering amino acids is small: glutamine, the major interfering compound, yields less than $1.5 \%$ of the colour given by an equivalent proline concentration. In addition, amino acid analysis showed that the amounts of other amino acids (notably glutamine) present in salt-stressed $B$. subtilis were negligible when compared with proline. Samples were harvested by centrifugation and extracted overnight in $1 \mathrm{ml} \mathrm{3 \%}(\mathrm{w} / \mathrm{v})$ aqueous 5 sulphosalicylic acid. Precipitated protein and other debris were removed by microcentrifugation. Acid ninhydrin was prepared by dissolving $1.25 \mathrm{~g}$ ninhydrin in $30 \mathrm{ml}$ glacial acetic acid and $20 \mathrm{ml} 6 \mathrm{M}$ $\mathrm{H}_{3} \mathrm{PO}_{4}$. The cellular extract was reacted with $0.5 \mathrm{ml}$ acid ninhydrin and $0.5 \mathrm{ml}$ glacial acetic acid at $100^{\circ} \mathrm{C}$ for $1 \mathrm{~h}$. Samples were then plunged into ice and the colour extracted by mixing vigorously with $2 \mathrm{ml}$ toluene. After $15 \mathrm{~min}$ the absorbance was read at $520 \mathrm{~nm}$ against a toluene blank.

A standard curve was prepared using $0.02-0.4 \mu \mathrm{mol} \mathrm{ml} \mathrm{m}^{-1}$ authentic proline in 3\% 5-sulphosalicylic acid. Intracellular concentrations of proline could be calculated since the total intracellular volume of all samples was determined by Coulter counter before harvesting.

Determination of intracellular $\mathrm{K}^{+}$. Following particle size analysis, cells were harvested either by centrifugation or by passage through glass-microfibre filters (Whatman GF/F). Samples were then rinsed thoroughly in isotonic $\mathrm{CaCl}_{2}$ to remove extracellular $\mathrm{K}^{+}$in the cell wall and the growth medium. The inorganic ions were then extracted overnight in $1 \mathrm{ml}$ concentrated $\mathrm{HNO}_{3}$. Each sample was then diluted as appropriate in distilled water and analysed for $\mathrm{K}^{+}$using a flame photometer (EEL, model 100). Quantification was with respect to an external standard curve (0.25-1.00 mM-KCl).

\section{Results}

\section{Natural abundance ${ }^{13}$ C NMR spectroscopy}

Fig. 1 shows the ${ }^{13} \mathrm{C}$ NMR spectra obtained from $B$. subtilis grown in basal medium with and without added $\mathrm{NaCl}(400 \mathrm{~mm})$. The resonances from $B$. subtilis grown in an increased salt concentration were identified as glutamic acid $(\delta=23.5,30.0,51.4,171.3$ and $177 \cdot 8$ p.p.m. $)$ and proline $(\delta=20 \cdot 6,25 \cdot 6,42 \cdot 9,58 \cdot 0$ and 171.3 p.p.m.) by reference to spectra from authentic compounds. As all other resonances were negligible, glutamic acid and proline are the only two organic compounds accumulated in osmotically significant quan- 

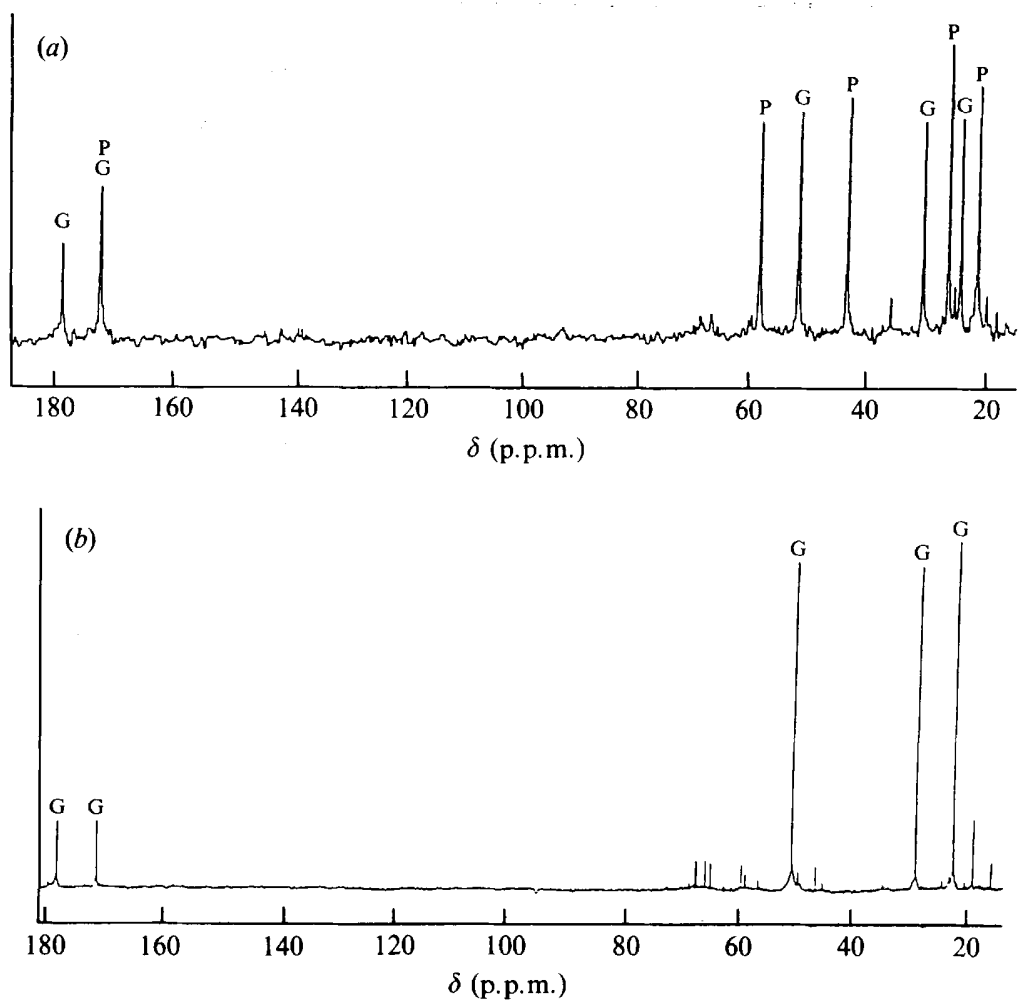

Fig. $1 .{ }^{13} \mathrm{C}$ NMR spectra of $B$. subtilis grown in the presence $(a)$ and absence $(b)$ of $400 \mathrm{mM}-\mathrm{NaCl}$ in defined medium at $25^{\circ} \mathrm{C}$. Resonances are not directly comparable, between the two spectra, due to differences in biomass and the absence of a reference (internal standard). G, glutamic acid; $P$, proline.

tities under these growth conditions. The spectrum obtained from $\boldsymbol{B}$. subtilis grown in basal medium showed glutamic acid was a major solute but no proline was detected. Hence it appears that proline may be the sole osmotically responsive endogenous organic solute in $B$. subtilis.

\section{Determination of free amino acid pools}

Table 1 gives details of the amino acid pools of $B$. subtilis at points prior to upshock, during recovery (i.e. at $2 \mathrm{~h}$, before growth had resumed), once exponential growth had resumed $(7 \mathrm{~h})$ and during the stationary phase $(25 \mathrm{~h})$. The results confirmed the NMR findings, since glutamic acid and proline were the only amino acids present in significant quantities. The total amino acid pool increased from $138 \mathrm{~mm}$ to $893 \mathrm{~mm} 7 \mathrm{~h}$ after upshock; at this point cells had recovered turgor (Whatmore \& Reed, $1990)$ and growth had resumed. By $25 \mathrm{~h}$ the total amino acid pool had fallen considerably, to $398 \mathrm{~mm}$. In unstressed cells, glutamic acid formed approximately $75 \%$ of the total amino acid pool but $7 \mathrm{~h}$ after upshock the glutamic acid proportion had fallen to $19 \%$ and the proportion of proline had risen to $80 \%$. Although the total amino acid pool declined in the stationary phase,
Table 1. Free amino acid pools of B. subtilis after osmotic upshock $(400 \mathrm{mM}-\mathrm{NaCl})$ in defined medium at $25^{\circ} \mathrm{C}$

All concentrations are expressed in mM. Other amino acids were not present in sufficient quantities to be detected.

\begin{tabular}{lcccr}
\hline & \multicolumn{5}{c}{ Amino acid pool } \\
\cline { 2 - 5 } $\begin{array}{l}\text { Time after } \\
\text { upshock (h) ... }\end{array}$ & 0 & 2 & 7 & 25 \\
\hline Glutamate & 103.2 & 157.6 & 167.4 & 61.6 \\
$\begin{array}{l}\text { Proline } \\
\text { Glycine }\end{array}$ & 16.4 & 188.2 & 705.4 & 318.2 \\
$\begin{array}{l}\text { Alanine } \\
\text { Aspartate }\end{array}$ & 10.4 & 12.9 & 10.1 & 7.3 \\
Ornithine & 2.6 & 5.9 & 7.5 & 7.0 \\
$\begin{array}{l}\text { Total free } \\
\text { amino acid pool }\end{array}$ & 0.64 & 0.43 & 0.80 & 1.28 \\
$\begin{array}{c}\text { Glutamate } \\
\text { (\% total) }\end{array}$ & 4.9 & 0.60 & 1.85 & 2.33 \\
Proline \\
(\% total)
\end{tabular}

the proportion of glutamic acid to proline remained similar. The concentration of proline rose some 43-fold after upshock while the glutamic acid pool increased by little more than half. The pools of other amino acids were 


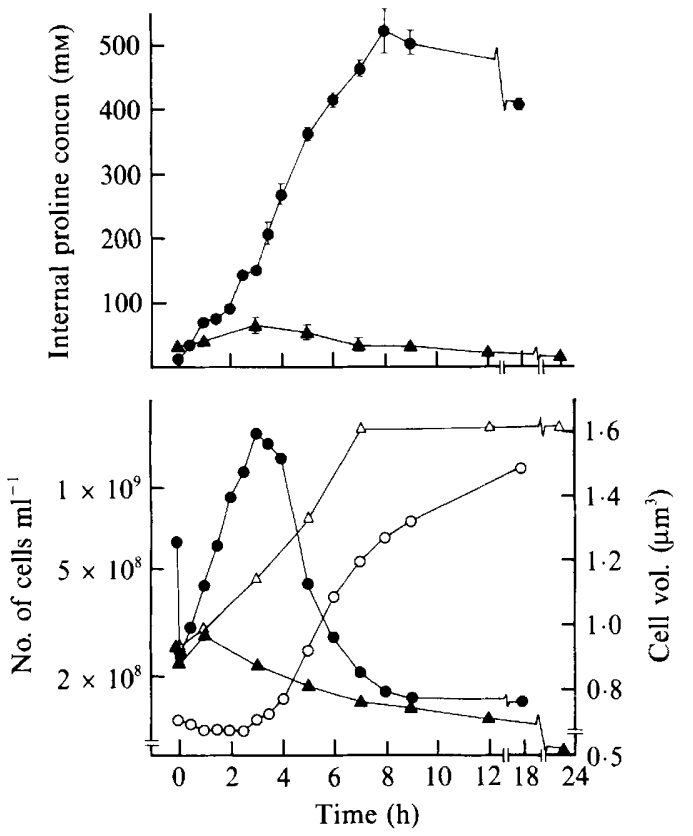

Fig. 2. (a) Effect of upshock with $400 \mathrm{~mm}-\mathrm{NaCl}$ on the internal proline concentration of $B$. subtilis in defined medium at $25^{\circ} \mathrm{C}$. Mean \pm $95 \%$ confidence limits of three or four replicates. Upshocked cells; $\boldsymbol{\Delta}$, non-stressed cells. (b) Corresponding mean cell volume and cell count data. Mean of four to six replicates. Mean cell volume: $\bullet$, upshocked cells; $\boldsymbol{\Delta}$, non-stressed cells. Cell number: $O$, upshocked cells; $\triangle$, non-stressed cells.

too small to be regarded as osmotically significant. It was noted that a significant quantity of an unknown ninhydrin-reactive compound was detected in the stationary phase sample.

\section{Accumulation of proline after upshock}

In all of the subsequent experiments the intracellular proline concentration was determined by the chemical assay in conjunction with biovolume density measurements obtained from the Coulter counter.

The effect of upshock with $400 \mathrm{~mm}-\mathrm{NaCl}$ on exponentially growing $B$. subtilis is shown in Fig. 2. The intracellular proline concentration rose steadily after upshock, reaching a peak of $520 \mathrm{~mm}$ after $8 \mathrm{~h}$ before falling somewhat as the cells entered stationary phase. Control cells, which were diluted by the same factor as shocked cells in basal medium (without added $\mathrm{NaCl}$ ) maintained a relatively constant proline level. The saltshocked cells showed a lag period of $3 \mathrm{~h}$ before growth resumed, while control cells showed no significant lag, with growth maintained throughout (Fig. $2 b$ ). Growth resumed prior to peak proline accumulation in cells and therefore maximal proline accumulation does not appear to be necessary for growth at high osmolality. As predicted by osmotic theory the mean cell volume fell

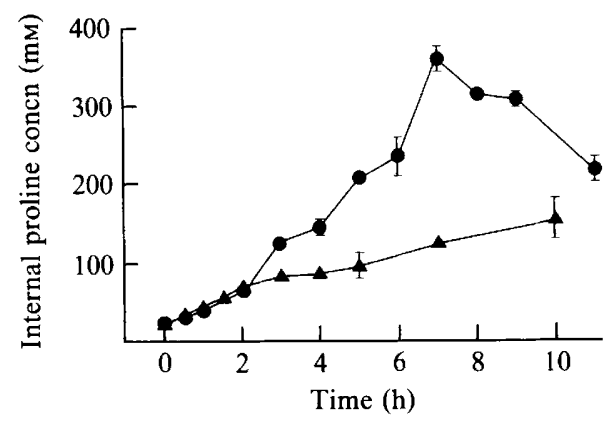

Fig. 3. Effect of upshock with $400 \mathrm{~mm}-\mathrm{NaCl}$ on the internal proline concentration after chloramphenicol treatment of $B$. subtilis grown in defined medium at $25^{\circ} \mathrm{C}$. Mean $\pm 95 \%$ confidence limits of three or four replicates. $\Delta$, Chloramphenicol-treated cells $\left(6 \mu \mathrm{g} \mathrm{ml}^{-1}, 60 \mathrm{~min}\right)$; ๑, control cells (salt-stress only).

sharply immediately after upshock but then rose rapidly over the next $3 \mathrm{~h}$ to a level considerably higher than that prior to upshock. After this point the mean cell volume of $\mathrm{NaCl}$-treated cells fell rapidly - the peak mean cell volume corresponded with the point at which cell division was resumed. Control cells maintained a less variable volume throughout, although the cells became somewhat smaller as they approached the stationary phase.

Fig. 3 shows the effects of pretreating cells with chloramphenicol before upshock in an attempt to determine whether proline synthesis was genetically induced or resulted from activation of existing enzymes by osmotic upshock. Cells were treated with $6 \mu \mathrm{g}$ chloramphenicol ml-1 for $1 \mathrm{~h}$ prior to upshock. The accumulation of proline in untreated and chloramphenicol-treated cells was virtually identical for the first $2 \mathrm{~h}$ after upshock. After this point proline levels in chloramphenicol-treated cells increased at a considerably slower rate than those of untreated cells. The mean cell volume of chloramphenicol-treated cells showed little recovery over the time course (data not shown) in contrast to that of control cells which showed the same characteristic peak seen previously (Fig. $2 b$ ). There was no increase in the cell number of chloramphenicol-treated cells over the course of the experiment.

\section{Accumulation of $\mathrm{K}^{+}$after upshock}

Fig. 4 shows the effect of upshock on the internal $\mathrm{K}^{+}$ levels of exponentially growing $B$. subtilis, in minimal medium both with and without the addition of $1 \mathrm{mM}-$ glycine betaine. In upshocked cells the $\mathrm{K}^{+}$level rose from a basal value of approximately $350 \mathrm{mM}$ to approximately $650 \mathrm{mM}$ within $1 \mathrm{~h}$. After this point the $\mathrm{K}^{+}$concentration remained relatively steady, at $600-725 \mathrm{mM}$, until the stationary phase when it fell sharply to around $200 \mathrm{mM}$. 


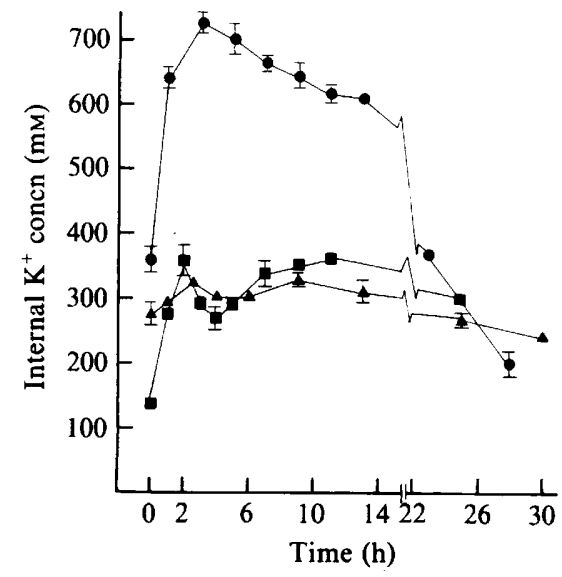

Fig. 4. Effect of upshock with $400 \mathrm{~mm}-\mathrm{NaCl}$ on the internal $\mathrm{K}^{+}$ concentration of $B$. subtilis grown in defined medium with and without 1 mM-glycine betaine at $25{ }^{\circ} \mathrm{C}$. Mean $\pm 95 \%$ confidence limits of three or four replicates. $\bullet$, Upshocked cells (no glycine betaine); $\Delta$, nonstressed cells (no glycine betaine); $\square$, upshocked cells (1 mM-glycine betaine).

In unstressed cells the $\mathrm{K}^{+}$level remained relatively constant during growth with a mean value of about $300 \mathrm{mM}$, with a slow decline during the stationary phase. Cell volume and cell number (data not shown) showed the same patterns as seen in the proline accumulation experiments, with a $3 \mathrm{~h}$ lag phase for salt-stressed cells, corresponding to a peak in cell volume at $3 \mathrm{~h}$.

\section{Effects of $\mathrm{K}^{+}$starvation on proline accumulation}

The effects of $\mathrm{K}^{+}$starvation on proline accumulation are shown in Fig. 5. This experiment was done by harvesting a large volume of exponentially growing cells, rinsing them in isotonic $\mathrm{CaCl}_{2}$ to remove all external $\mathrm{K}^{+}$and then resuspending them in a small volume of $\mathrm{K}^{+}$-free basal medium. This cell suspension was then split into three equal volumes and resuspended in three flasks of medium containing $400 \mathrm{mM}-\mathrm{NaCl}$. One flask contained complete $\left(\mathrm{K}^{+}\right.$-sufficient medium) while the remaining flasks contained $\mathrm{K}^{+}$-free medium. $\mathrm{KCl}(5 \mathrm{~mm})$ was added to one of the latter flasks after $22 \mathrm{~h}$.

In the presence of exogenous $\mathrm{K}^{+}$proline was accumulated as in previous experiments, with a steady rise over $9 \mathrm{~h}$ to approximately $420 \mathrm{~mm}$ before declining in the stationary phase to $45 \mathrm{~mm}$. In the absence of $\mathrm{K}^{+}$there was relatively little accumulation of proline, with a maximum level of $100 \mathrm{~mm}$. In the remaining culture there was similarly no accumulation of proline until $\mathrm{KCl}$ was added after $22 \mathrm{~h}$. Within $1 \mathrm{~h}$ of this addition the proline level rose sharply and peaked at approximately $500 \mathrm{~mm}$ after $7 \mathrm{~h}$. Growth and volume data (Fig. $5 b, c$ ) showed the responses that would be predicted from previous experiments. The culture in $\mathrm{K}^{+}$-sufficient

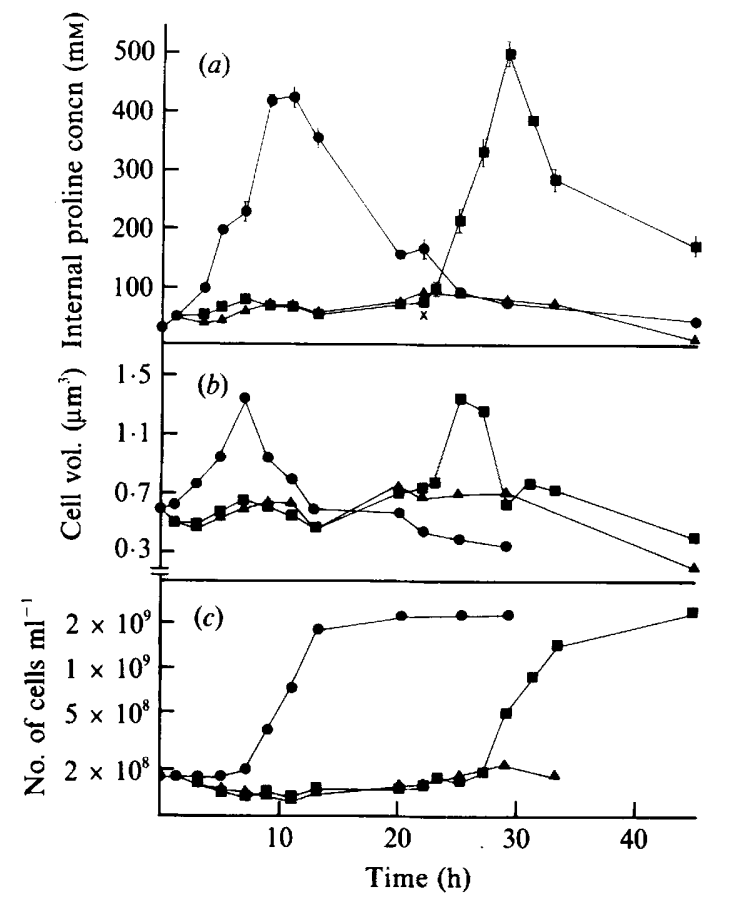

Fig. 5. (a) Effect of exogenous $\mathrm{K}^{+}$on proline accumulation after $400 \mathrm{~mm}-\mathrm{NaCl}$ upshock of $B$. subtilis in defined medium at $25^{\circ} \mathrm{C}$. Cells were harvested and rinsed in isotonic $\mathrm{CaCl}_{2}$ before being resuspended in growth medium ( $\pm \mathrm{KCl}$, as required) with $400 \mathrm{~mm}-\mathrm{NaCl}$. Mean \pm $95 \%$ confidence limits of three or four replicates. $\times$ Marks the point at which $\mathrm{K}^{+}$( $5 \mathrm{~mm}$ was added). (b) Corresponding cell volume data. (c) Corresponding cell number data. Symbols for $(a),(b)$ and $(c): 0,5 \mathrm{mM}-$ $\mathrm{KCl}$ in medium; $\mathbf{\square}, 5 \mathrm{~mm}-\mathrm{KCl}$ added $22 \mathrm{~h}$ after upshock; $\Delta, \mathrm{K}^{+}$-free medium.

medium showed a lag of approximately $4 \mathrm{~h}$ before growth resumed. The culture devoid of $\mathrm{K}^{+}$showed no significant increase in cell number over the course of the experiment while in the remaining culture growth resumed at $25 \mathrm{~h}$. The $\mathrm{K}^{+}$-sufficient culture showed the normal pattern of volume recovery while the $\mathrm{K}^{+}$-deplete culture showed no volume recovery. The remaining culture showed a rapid rise in volume after addition of $\mathrm{KCl}$ at $22 \mathrm{~h}$, peaking at $24 \mathrm{~h}$.

\section{Accumulation of solutes in the presence of exogenous glycine betaine}

The effect of upshock on solute levels of cells grown in the presence of $1 \mathrm{~mm}$-glycine betaine was examined. Glycine betaine is not synthesized by $B$. subtilis grown in defined medium under these conditions, as shown by ${ }^{13} \mathrm{C}$ NMR (Fig. 1). However, it is known to act as a compatible solute in many bacteria if available externally (Imhoff \& Rodriguez-Valera, 1984).

Fig. 6 shows the effect of osmotic upshock on levels of glycine betaine and proline in cells grown and upshocked 


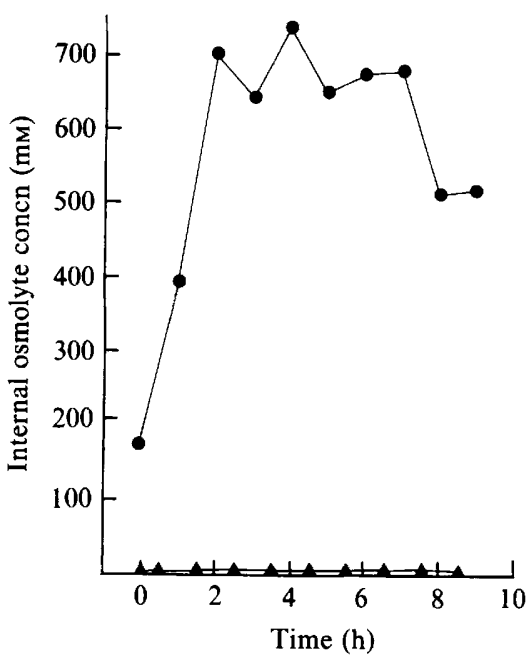

Fig. 6. Effect of upshock with $400 \mathrm{~mm}-\mathrm{NaCl}$ on internal glycine betaine and proline concentrations of $\boldsymbol{B}$. subtilis grown in defined medium with $1 \mathrm{~mm}$-glycine betaine at $25^{\circ} \mathrm{C}$., Glycine betaine (data from a single sample); $\boldsymbol{\Delta}$, proline (mean of three or four replicates).

in the presence of $1 \mathrm{~mm}$-glycine betaine. From a level of approximately $175 \mathrm{~mm}$ in basal medium glycine betaine rose within $2 \mathrm{~h}$ of upshock to approximately $700 \mathrm{~mm}$ and remained relatively steady for the next $5 \mathrm{~h}$ before falling somewhat in the late exponential phase. Experiments done with killed cells confirmed that the rather high levels of glycine betaine detected did not result from significant carry over from the growth medium (Whatmore, 1989). The level of proline detected in these cells was very low: in basal medium before upshock there was only $6 \mathrm{~mm}$-proline, somewhat less than the 10-20 mM generally seen in cells grown in basal medium without glycine betaine. After upshock, proline levels showed no substantial increase remaining below $10 \mathrm{~mm}$ throughout.

Fig. 4 shows the effect of upshock on internal $\mathrm{K}^{+}$ concentration for cells shocked in a medium with added glycine betaine. As before, there was a considerable rise in internal $\mathrm{K}^{+}$concentration after upshock, though the initial level of $135 \mathrm{~mm}$ and the maximum level $(360 \mathrm{~mm})$ attained were considerably lower than those found in cells grown without glycine betaine. After $2 \mathrm{~h}, \mathrm{~K}^{+}$levels remained at $275-375 \mathrm{~mm}$ throughout the experiment.

\section{Discussion}

Natural abundance ${ }^{13} \mathrm{C}$ NMR revealed only proline as a major endogenous organic osmolyte in $B$. subtilis grown in minimal medium. Amino acid analysis confirmed NMR findings: glutamic acid was not substantially accumulated in response to upshock in contrast to Gramnegative bacteria (Measures, 1975). The small increase seen at $2 \mathrm{~h}$ (Table 1) may be due to increased activity in the biosynthetic pathway leading to proline (Hayzer \& Leisinger, 1980). No evidence was obtained of significant accumulation of any of the other neutral amino acids found in other Gram-positive bacteria. The unidentified ninhydrin-reactive compound, which did not correspond to any of the known amino acid standards, appeared in significant quantities only in stationary phase cells, suggesting its role was probably not osmotic; it may be a storage compound or a metabolite involved in sporulation.

The accumulation of proline after upshock was somewhat less rapid than previously reported for osmotically stressed $B$. subtilis (Gould \& Measures, 1977), when growth recommenced after a few minutes. The differences between the present study and previous work in the time-scale of proline accumulation and the resumption of growth may be due to variations in cultural conditions/medium composition, strain differences or variation in other environmental determinants. Adding exogenous proline $(1 \mathrm{mM})$ or raising the growth temperature to $37^{\circ} \mathrm{C}$ reduced the lag period to under $2 \mathrm{~h}$ (Whatmore, 1989). Interestingly, the level of proline synthesized after shock at $37^{\circ} \mathrm{C}(180 \mathrm{mM})$ was considerably lower than that seen at $25^{\circ} \mathrm{C}(520 \mathrm{mM}$, Fig. 2). Similar phenomena have been reported in both cyanobacteria (Warr et al., 1985) and in heterotrophic halophilic eubacteria of the family Halomonadaceae (Wohlfarth et al., 1990), where the nature of the osmolyte pool has also been shown to vary with temperature. It seems that at more favourable temperatures $B$. subtilis can tolerate osmotic stress with a reduced level of intracellular proline, although it is not known whether this is due to the accumulation of alternative solutes or to changes in the relationship between turgor and growth with temperature, e.g. due to variations in cell wall composition.

The addition of chloramphenicol prior to upshock produced an effect similar to that on the osmotically regulated trehalose phosphate synthase of $E$. coli, where a slow accumulation of trehalose relative to that of control cells was seen after upshock (Dinnibier et al., 1988). Proline synthesis in chloramphenicol treated and untreated upshocked $B$. subtilis cells was identical over the first $2 \mathrm{~h}$; accumulation in chloramphenicol-treated cells was then severely curtailed. This observation, and the fact that throughout this study no lag was observed between upshock and the onset of proline synthesis, suggests that at least some of the accumulation was due to activation of pre-existing enzyme. However, some protein synthesis appears to be necessary for maximal sustained synthesis of proline.

Data presented in Fig. 4 imply that $\mathrm{K}^{+}$also plays a role in osmotic adjustment in $B$. subtilis, since the $\mathrm{K}^{+}$level 
more than doubled after upshock. This effect was more rapid than for proline accumulation and must reflect a stimulation of (active) net $\mathrm{K}^{+}$influx by increased external osmotic pressure. Hence the restoration of turgor pressure in B. subtilis appears to be the result of the accumulation of two principal osmolytes (in the absence of exogenous organic solutes). An initial rapid accumulation of $\mathrm{K}^{+}$from the external medium is followed by a slower accumulation of proline synthesized by the cell. It appears that the short-term accumulation of $\mathrm{K}^{+}$followed by long-term accumulation of more compatible organic solutes may be a common osmoregulatory mechanism employed by a range of micro-organisms (Epstein, 1986; Booth et al., 1988). Similar mechanisms are known to operate in enteric Gram-negative bacteria (Dinnibier $e t$ al., 1988) and in a number of cyanobacteria (Reed \& Stewart, 1985; Reed et al., 1985b). In these organisms there is an energy-dependent $\mathrm{K}^{+}$uptake system which responds directly to changes in turgor. The present study has provided novel evidence for the involvement of $\mathrm{K}^{+}$ in the turgor regulation of $B$. subtilis. Data presented in Fig. 5 show that $\mathrm{K}^{+}$is essential for proline synthesis and consequent recovery of growth following osmotic upshock. In addition, we demonstrated in the preceding paper (Whatmore \& Reed, 1990) that $\mathrm{K}^{+}$is essential for recovery of turgor pressure after upshock. Hence it can be postulated that $B$. subtilis has a turgor-sensitive $\mathrm{K}^{+}$ uptake system similar in function to the system characterized for E. coli (Epstein, 1986).

A model similar in principle to that which operates in $E$. coli can be proposed for the response of $B$. subtilis to osmotic upshock. After upshock the outflow of water and subsequent loss of turgor will activate $\mathrm{K}^{+}$uptake. If upshock is only slight, the accumulation of $\mathrm{K}^{+}$alone may be sufficient to restore turgor. Thus cells grown in $200 \mathrm{mM}-\mathrm{NaCl}$ showed negligible increases in internal proline concentration but significant increases in $\mathrm{K}^{+}$ concentration over the same range (Whatmore, 1989). However, if upshock is more substantial, accumulation of $\mathrm{K}^{+}$will lead to induction and/or activation of proline biosynthetic enzymes, since accumulation of excessive $\mathrm{K}^{+}$may be potentially deleterious to cellular metabolism (Sutherland et al., 1986; Booth et al., 1988). $\mathrm{K}^{+}$has now been shown to exert its effects in upshocked enteric bacteria via the induction of glycine betaine uptake (pro $U$-mediated) due to alteration of DNA structure. Increased osmotic strength leads to an increase in DNA supercoiling which results in activation of transcription from the proU promoter (Higgins et al., 1988).

Measures (1975) showed that the glutamate biosynthetic enzymes (GDH \& GOGAT) of many bacteria were $\mathrm{K}^{+}$-stimulated and Giaever et al. (1988) showed that the trehalose phosphate synthase of $E$. coli is both osmotically induced and $\mathrm{K}^{+}$-activated. The genes and enzymes of proline biosynthesis have been characterized in a number of micro-organisms including $E$. coli (Hayzer \& Leisinger, 1980), Pseudomonas aeruginosa (Krishna \& Leisinger, 1979) and Saccharomyces cerevisiae (Tomenchok \& Brandriss, 1987). Proline biosynthesis in all of these organisms occurs via a series of three enzymic reactions and regulation of synthesis is exerted primarily through feedback inhibition of $\gamma$-glutamyl kinase, the first enzyme of the pathway, by proline. Since the $\gamma$ glutamyl kinase of Gram-negative organisms is inhibited by relatively low proline concentrations $(50 \%$ inhibition by 5 mM-proline: Krishna \& Leisinger, 1979) the regulation of this pathway in proline-producing, salt tolerant Gram-positive bacteria must be somewhat different. Little is known about proline synthesis in Gram-positive bacteria but it is noteworthy that Yoshinaga $e$ al. (1975) purified a $\gamma$-glutamyl kinase from the Gram-positive bacterium Brevibacterium flavum which was unaffected by proline.

The induction of stress proteins in salt-shocked $B$. subtilis has recently been examined by Hecker et al. (1988). Salt stress was extremely effective in the induction of at least 14 general stress proteins as well as three proteins induced only by osmotic stress. The nature of these three proteins was not examined but it is possible that they may represent the three enzymes of the proline biosynthetic pathway.

An obvious question concerns the nature of the counter-ion to $\mathrm{K}^{+}$in $B$. subtilis. Glutamate is known to be accumulated as the counter-ion to $\mathrm{K}^{+}$in $E$. coli (Larsen $e t$ al., 1987). However, glutamate levels increased only slightly after upshock and could account only for a small proportion of the required counter-ion (about 15\%, based on Table 1 and Fig. 4). Natural abundance ${ }^{13} \mathrm{C}$ NMR spectroscopy showed that any other counter-ion present could not be an organic molecule. The intracellular levels of inorganic anions were not measured in this study but $\mathrm{Cl}^{-}$is the most likely candidate for the counterion. Killham \& Firestone (1984) have shown that $\mathrm{Cl}^{-}$ increases correspondingly as $\mathrm{K}^{+}$rises in Streptomyces $\mathrm{sp}$. transferred to a higher osmolality medium. It is also possible that efflux of $\mathrm{Na}^{+}$may help balance the influx of $\mathrm{K}^{+}$, as in some cyanobacteria (Reed et al., 1985b). It should be noted that methods employed in this study measured the total potassium content of cells rather than free $\mathrm{K}^{+}$alone - only free ions will act as osmolytes. If cation solutes such as $\mathrm{K}^{+}$are bound to negatively charged components of high molecular mass within the cell their osmotic significance will be greatly reduced. Richey et al. (1987) concluded that, due to binding to cellular components, the cytoplasmic $\mathrm{K}^{+}$concentration was only half the total $\mathrm{K}^{+}$in E. coli. Tempest et al. (1970) have also reported that osmotic stress leads to alkalinization of the cytoplasm, though Dinnibier et al. (1988) 
reported that this was a transient phenomenon, and hence the expulsion of $\mathrm{H}^{+}$could account for a proportion of the accumulated $\mathrm{K}^{+}$.

The osmolytes accumulated by $B$. subtilis in response to upshock with $400 \mathrm{~mm}-\mathrm{NaCl}$ can be shown to be sufficient to regenerate turgor, though we believe such calculations to be a somewhat simplistic approach to a complex system. Upshock with $400 \mathrm{mM}-\mathrm{NaCl}$ will raise the external osmolality by $0.740 \mathrm{osmol} \mathrm{kg} \mathrm{kg}^{-1}$. Results in the preceding paper (Whatmore \& Reed, 1990) showed that turgor is restored within $5 \mathrm{~h}$ of upshock; hence if the proline concentration is taken as $360 \mathrm{mM}$ (from Fig. 2) and the increase in $\mathrm{K}^{+}$concentration as $340 \mathrm{mM}$ (from Fig. 4) the resulting osmolalities generated by these solutes are $0.380 \mathrm{osmol} \mathrm{kg}^{-1}$ and $0.306 \mathrm{osmol} \mathrm{kg}^{-1}$ respectively (by use of a cryoscopic osmometer). The sum of the osmolalities generated by these two solutes, at $0.686 \mathrm{osmol} \mathrm{kg} \mathrm{kg}^{-1}$, approaches the external osmolality increase of 0.740 osmol kg-1. No account is taken of the necessary counter-ion of $\mathrm{K}^{+}$in this analysis, but equally there may be unaccounted effluxes as noted above. If the solute concentrations are expressed in terms of cell osmotic volume at $60-70 \%$ of total cell volume (Whatmore \& Reed, 1990), the net increase in internal osmolality would be considerably higher.

The response of $B$. subtilis to upshock was markedly different in the presence of glycine betaine. Glycine betaine was accumulated as a compatible solute with no synthesis of proline. This may reflect the status of glycine betaine as a more effective osmoprotective solute due to an enhanced compatibility with enzyme function (Warr et al., 1988). The $\mathrm{K}^{+}$level was elevated immediately after upshock of $B$. subtilis in the presence of glycine betaine. However, the $\mathrm{K}^{+}$pool was consistently smaller in the presence of glycine betaine. Hence it appears that the intracellular $\mathrm{K}^{+}$concentration may be involved in both the regulation of proline biosynthesis and the uptake of exogenous compatible solute, if available, after osmotic upshock.

Thanks to Dr P. Rowell for assistance with the amino acid analysis. This research was supported by a SERC studentship to A.M.W.

\section{References}

ANDERson, C. B. \& WrTter, L. D. (1982). Glutamine and proline accumulation by Staphylococcus aureus with reduction in water activity. Applied and Environmental Microbiology 43, 1501-1503.

Bates, L. S., Waldren, R. P. \& Teare, I. D. (1973). Rapid determination of free proline for water stress studies. Plant and Soil 39, 205-207.

Booth, I. R., Cairney, J., Sutherland, L. \& Higgins, C. F. (1988). Enteric bacteria and osmotic stress: an integrated homeostatic system. Journal of Applied Bacteriology Symposium Supplement 35S$39 \mathrm{~S}$.
Brown, A. D. (1976). Microbial water stress. Bacteriological Reviews 40, 803-846.

BRown, A. D. \& Simpson, J. R. (1972). Water relations of sugar tolerant yeasts: the role of intracellular polyols. Journal of General Microbiology 72, 589-591.

Chudek, J. A., Foster, R., Moore, D. \& Reed, R. H. (1987). Identification and quantification of methylated osmolytes in algae using proton nuclear magnetic resonance spectroscopy. British Phycological Journal 22, 169-173.

Csonka, L. N. (1989). Physiological and genetic responses of bacteria to osmotic stress. Microbiological Reviews 53, 121-147.

DiNNIBIER, U., LIMPINSEL, E., SCHMID, R. \& BAKKER, E. P. (1988). Transient accumulation of potassium glutamate and its replacement by trehalose during adaption of growing cells of Escherichia coli to elevated sodium chloride concentrations. Archives of Microbiology 150, 348-357.

EPSTEIN, W. (1986). Osmoregulation by potassium transport in Escherichia coli. FEMS Microbiology Reviews 39, 73-78.

Gadd, G. M., Chudex, J. A., Foster, R. \& Reed, R. H. (1984). The osmotic responses of Penicillium ochro-chloron: changes in internal solute levels in response to copper and salt stress. Journal of General Microbiology 130, 1969-1975.

Giaever, H. M., Stryvold, O. B., KaASEn, I. \& Strom, A. R. (1988). Biochemical and genetic characterization of osmoregulatory trehalose synthesis in Escherichia coli. Journal of Bacteriology 170, 28412849.

Gould, G. W. \& Measures, J. C. (1977). Water relations in single cells. Philosophical Transactions of the Royal Society of London 278, 151-166.

HAYZER, D. J. \& LEISINGER, T. (1980). The gene-enzyme relationships of proline biosynthesis in Escherichia coli. Journal of General Microbiology 118, 287-293.

HeCKeR, M., Heim, M., VolKer, U. \& WolFel, L. (1988). Induction of stress proteins by sodium chloride treatment in Bacillus subtilis. Archives of Microbiology 150, 564-566.

Higgins, C. F., Cairney, J., Stirling, J. A., Sutherland, L. \& BooTH, I. R. (1987). Osmotic regulation of gene expression: ionic strength as an intracellular signal? Trends in Biochemical Sciences 12, 339-344.

Higgins, C. F., Dorman, C. J., Sttring, J. A., Waddell, L., Booth, I. R., MAY, G. \& BREMER, E. (1988). A physiological role for DNA supercoiling in the osmotic regulation of gene expression in Salmonella typhimurium and Escherichia coli. Cell 52, 569-584.

Hutkins, R. W., Gilefson, W. L. \& KashKet, E. R. (1987). Betaine transport imparts osmotolerance on a strain of Lactobacillus acidophilus. Applied and Environmental Microbiology 53, 2275-2281.

IMHOFF, J. F. (1986). Osmoregulation and compatible solutes in eubacteria. FEMS Microbiology Reviews 39, 57-66.

IMHOFF, J. F. \& RODRIGUEZ-VALERA, F. (1984). Betaine is the main compatible solute of halophilic eubacteria. Journal of Bacteriology 160, 478-479.

Killham, K. \& Firestone, M. K. (1984). Salt stress control of intracellular solutes in Streptomyces indigenous to saline soils. Applied and Environmental Microbiology 47, 301-306.

KRISHNA, R. V. \& LeISINGER, T. (1979). Biosynthesis of proline in Pseudomonas aeuruginosa. Biochemical Journal 181, 215-222.

Larsen, P. I., Sydnes, L. K., Landfald, B. \& Strom, A. R. (1987). Osmoregulation in Escherichia coli by accumulation of organic osmolytes: betaines, glutamic acid and trehalose. Archives of Microbiology 147, 1-7.

MEASURES, J. C. (1975). Role of amino acids in osmoregulation of nonhalophilic bacteria. Nature, London 257, 398-400.

REED, R. H. \& STEWART, W. D. P. (1985). Evidence for turgor sensitive $\mathrm{K}^{+}$influx in the cyanobacteria Anabaena variabilis ATCC 29413 and Synechocystis PCC 6714. Biochimica et Biophysica Acta 812, 155-162.

ReED, R. H., Collins, J. C. \& Russell, G. (1980). The effects of salinity upon galactosyl-glycerol content and concentration of the marine red alga Porphyra purpurea (Roth) C. Ag. Journal of Experimental Botany 31, 1539-1554.

Reed, R. H., Davison, I. R., Chudek, J. A. \& Foster, R. (1985a). The osmotic role of mannitol in the Phaeophyta: an appraisal. Phycologia 24, 35-47. 
ReED, R. H., WarR, S. R. C., Richardson, D. L., MOORE, D. J. \& STEWART, W. D. P. (1985b). Multiphasic osmotic adjustment in a euryhaline cyanobacterium. FEMS Microbiology Letters 28, 225229.

Richey, B., Scott Cayley, D., Mossing, M. C., Kalka, C., ANDERSON, C. F., FARRAR, T. C. \& RECORD, M. (1987). Variability of the intracellular ionic environment of Escherichia coli. Journal of Biological Chemistry 262, 7157-7164.

Sutherland, L., Cairney, J., Elmore, M. J., Booth, I. R. \& Higgins, C. F. (1986). Osmotic regulation of transcription: induction of the proU betaine transport gene is dependent on accumulation of intracellular potassium. Journal of Bacteriology 168, 805-814.

Tempest, D. W., Meers, J. L. \& Brown, C. M. (1970) Influence of environment on the content and composition of microbial free amino acid pools. Journal of General Microbiology 64, 171-185.

TOMENCHOK, D. M. \& BRANDRISS, M. C. (1987). Gene-enzyme relationships in the proline biosynthetic pathway of Saccharomyces cerevisiae. Journal of Bacteriology 169, 5364-5372.

Wark, S. R. C., ReEd, R. H. \& Stewart, W. D. P. (1985). Carbohydrate accumulation in osmotically stressed cyanobacteria (blue-green algae): interactions of temperature and salinity. New Phytologist 100, 285-292.

WarR, S. R. C., Reed, R. H. \& Stewart, W. D. P. (1988). The compatibility of osmotica in cyanobacteria. Plant Cell and Environment 11, 137-142.

WhATMORE, A. M. (1989). Osmotic responses of Bacillus subtilis. MSc thesis, University of Dundee, UK.

Whatmore, A. M. \& Reed, R. H. (1990). Determination of turgor pressure of Bacillus subtilis: a possible role for $\mathrm{K}^{+}$in turgor regulation. Journal of General Microbiology 136, 2521-2526.

Wohlfarth, A., Severin, J. \& Galinski, E. A. (1990). The spectrum of compatible solutes in heterotrophic halophilic eubacteria of the family Halomonadaceae. Journal of General Microbiology 136, 705712.

Yoshinaga, F., Tsuchida, T. \& Okumura, S. (1975). Purification and properties of glutamyl kinases for L-proline and L-glutamine biosynthesis in Brevibacterium flavum. Agricultural and Biological Chemistry 39, 1269-1273. 